\title{
Diatom ooze-A large marine mercury sink
}

\author{
Sara Zaferani, Marta Pérez-Rodríguez, Harald Biester* \\ Institut für Geoökologie AG Umweltgeochemie, Technische Universität Braunschweig, Germany. \\ *Corresponding author. Email: h.biester@tu-bs.de
}

The role of algae for sequestration of atmospheric mercury in the ocean is largely unknown due to the lack of marine sediment data. We estimated Holocene global mercury accumulation in biogenic siliceous sediments (diatom ooze) based on high resolution cores from marine Antarctica. Diatom ooze exhibits the highest mercury accumulation rates ever reported for the marine environment and provided a large sink of anthropogenic mercury, surpassing existing model estimates up to seven fold. Anthropogenic pollution of the Southern Ocean began $\sim 150$ years ago and up to $20 \%$ of anthropogenic mercury emitted to the atmosphere may have been stored in diatom ooze. These findings reveal the crucial role of diatoms as a fast vector for mercury sequestration and diatom ooze as a large marine mercury sink.

Due to the scarcity of archive data from the marine environment the role of primary production and biogenic sediments for natural and anthropogenic mercury $(\mathrm{Hg})$ sequestration in the oceans is poorly understood. In the open ocean most $\mathrm{Hg}$ is received by atmospheric deposition and to a minor extent by discharge from rivers and most atmospheric $\mathrm{Hg}$ is thought to be reemitted $(1,2)$. Available data on global $\mathrm{Hg}$ burial in marine sediments are based on model estimates $(1,3)$. These studies estimate that the amount of $\mathrm{Hg}$ buried in open ocean sediments is relatively low (190-200 Mg yr-1 (2, 4)). Several studies indicate that the marine $\mathrm{Hg}$ cycle is closely related to biological productivity and that $\mathrm{Hg}$ scavenging by organic particles is an important vector for $\mathrm{Hg}$ burial in sediments (5-7). However, the contribution of these processes to the accumulation of $\mathrm{Hg}$ in marine sediments and the overall marine $\mathrm{Hg}$ mass balance in the oceans is not known.

Diatoms are a major group of microalgae, and their remains make up pelagic sediments called diatom ooze (DO), which cover $\sim 11 \%$ of the ocean floor (8) and show highest accumulation in the Southern Ocean $(9,10)$. Up to now, no high resolution ( $<50$ years) $\mathrm{Hg}$ record from ocean sediment is available, which allows calculation of global marine $\mathrm{Hg}$ sequestration and data on $\mathrm{Hg}$ in the ocean is limited to water column measurements (7).

Here we show high resolution Holocene $\mathrm{Hg}$ records from diatom ooze sediment cores taken at three basins around Antarctica: Adélie Basin (AB) (IODP318-U1357), Prydz Bay (PrB) (ODP119-740) and Palmer Basin (PB) (ODP178-1098) (Fig. 1). From these cores and modeled marine biogenic silica (BSi) sequestration we evaluated the role of diatom ooze as a Holocene $\mathrm{Hg}$ sink and estimated the global amount of $\mathrm{Hg}$ accumulated in diatom ooze. In addition, we reconstructed the chronology of $\mathrm{Hg}$ accumulation and anthropogenic atmospheric Hg pollution during the past 8600 years from annually laminated Adélie Basin sediments at a resolution of 10-20 and 200 years.

Composition of the sediment at the three locations is similar (Fig. 2) showing high $\mathrm{SiO}_{2}$ concentrations of $53 \%$ (PB), $66 \%(\mathrm{PrB})$ and $70 \%(\mathrm{AB})$, respectively, which identifies the sediments as diatom ooze (11-13). Principal component analyses reveal that $\mathrm{Hg}$ generally shows low or no positive covariance with lithogenic elements (e.g., Al, Ti, $\mathrm{Zr}$ (fig. S1)). This indicates that binding of atmospheric derived $\mathrm{Hg}$ to microalgae particles is the dominant process of $\mathrm{Hg}$ accumulation in these sediments and that terrestrial influences are negligible. The upper core sections contain median $\mathrm{Hg}$ concentrations between 55.6 and $70.9 \mathrm{ng} \mathrm{g}^{-1}$ and, thereby, exceed the median background (lower core section) concentrations between 32.1 and $36.0 \mathrm{ng} \mathrm{g}^{-1}$ by a factor of 2.2 (Fig. 3). Maximum concentrations reached $73.0(\mathrm{~PB}), 84.5(\mathrm{AB})$ and $86.6 \mathrm{ng} \mathrm{g}^{-1}(\mathrm{PrB})$. This strong increase in $\mathrm{Hg}$ concentrations in the upper core sections likely results from the 2-5-fold increase in global atmospheric $\mathrm{Hg}$ loads due to industrial $\mathrm{Hg}$ emissions in the past two centuries (14). These concentrations are similar to those found in other marine sediments (15). In the lower core sections $\mathrm{Hg}$ concentrations vary little only (Fig. 3), but exhibit dilution effects at higher silica concentrations (see Si-normalized $\mathrm{Hg}$ concentrations in fig. S2). Similar $\mathrm{Hg}$ concentrations in the three cores taken at locations separated thousands of kilometers indicate the absence of strong local effects and suggest that $\mathrm{Hg}$ concentrations in diatom ooze are related to concentrations of dissolved $\mathrm{Hg}$ in seawater, which are controlled by atmospheric $\mathrm{Hg}$ deposition and the Henry's Law constant as well as scavenging and mineralization processes of sinking particles.

Due to the consistency in $\mathrm{Hg}$ concentrations, the different sedimentation rates of the three cores control the large differences in $\mathrm{Hg}$ accumulation rates $\left(\mathrm{Hg}_{\mathrm{AR}}\right)$. The extremely high 
sedimentation rates $\left(\sim 2 \mathrm{~cm} \mathrm{yr}^{-1}\right)$ of $\mathrm{AB}$ sediments lead to $\mathrm{Hg}_{\mathrm{AR}}$ that are the highest ever reported from remote marine areas (median rates of 576 and $1200 \mu \mathrm{g} \mathrm{m}^{-2} \mathrm{yr}^{-1}$ for the pre-industrial and industrial (after 1850) period, respectively) (Fig. 3). These values even exceed those reported from estuaries and shelf areas (60-700 $\left.\mathrm{g} \mathrm{m} \mathrm{m}^{-2} \mathrm{yr}^{-1}\right)(16)$, which have hitherto been ranked as the largest marine $\mathrm{Hg}$ sink (17). The lower sedimentation rates of the $\mathrm{PrB}$ and $\mathrm{PB}$ cores produce lower $\mathrm{Hg}_{\mathrm{AR}}(\mathrm{PrB}$ median: 16.8 and $33.3 \mu \mathrm{g} \mathrm{m}^{-2} \mathrm{yr}^{-1}$; PB median: 124 and $192 \mu \mathrm{g}$ $\mathrm{m}^{-2} \mathrm{yr}^{-1}$ for the lower section and upper section of the cores, respectively), although still high relative to previously reported values indicating areas with high accumulation of diatom ooze as large $\mathrm{Hg}$ sinks.

To quantify the role of diatom ooze sediments for $\mathrm{Hg}$ sequestration in the oceans, we used the estimated total area of pelagic diatom ooze sediments of $23.3-31.1 \mathrm{Mio} \mathrm{km}^{2}(10,18)$. Due to the high sedimentation rates of our Antarctic cores, which may lead to large overestimation of global $\mathrm{Hg}_{\mathrm{AR}}$ in diatom ooze $\left(\mathrm{DOHg}_{\mathrm{AR}}\right)$, we applied two independent approaches for $\mathrm{DOHg}_{\mathrm{AR}}$ calculation. For calculation 1 (Calc.1) we used the diatom ooze sedimentation rates suggested for the Southern Ocean $\left(0.75 \mathrm{~mm} \mathrm{yr}^{-1}(19)\right)$ (dry mass accumulation rate of $0.68 \mathrm{~kg} \mathrm{~m}^{-2} \mathrm{yr}^{-1}$ ) in combination with median $\mathrm{Hg}$ concentrations (pre-industrial and industrial period) derived from our Antarctic cores. For calculation 2 (Calc. 2), we used published estimates of global annual BSi accumulation rates and different diatom preservation rates $(30 \%, 60 \%, 80 \%)$ combined with median $\mathrm{Si} / \mathrm{Hg}$ ratios from our cores for the pre-industrial and industrial period, respectively (Table 1).

Average $\mathrm{DOHg}_{\mathrm{AR}}$ for the industrial period range between 850 and $1166 \mathrm{Mg} \mathrm{yr}^{-1}$ (Table 1), which is by a factor of $\sim 4.5$ and 6.1 higher than estimates of existing model approaches $\left(190 \mathrm{Mg} \mathrm{yr}^{-1}\right)(1,3)$ for burial of $\mathrm{Hg}$ in deep ocean sediments indicating that $\mathrm{Hg}$ sequestration in biogenic marine sediments appear to have been hitherto largely underestimated. Pre-industrial $\mathrm{DOHg}_{\mathrm{AR}}$ range between 497 and $689 \mathrm{Mg} \mathrm{yr}^{-1}$, which is by a factor of 1.7 lower than those calculated for the industrial period. Although diatom ooze sedimentation and preservation in the Southern Ocean is known to be generally high $(>86 \%)(20)$, we additionally calculated two conservative approaches using the lowest reported diatom ooze sedimentation rate $\left(\sim 0.01 \mathrm{~mm} \mathrm{yr}^{-1}\right)(21,22)$ and the lowest published BSi preservation rate (3\%) (23). This calculations reveal DOH$\mathrm{g}_{\mathrm{AR}}$ of 18 and $38 \mathrm{Mg} \mathrm{yr}^{-1}$ which still account for 9 and $20 \%$ of the model estimate $\left(190 \mathrm{Mg} \mathrm{yr}^{-1}\right)$, respectively $(1,3)$ and underlines the importance of $\mathrm{Hg}$ sequestration in diatom ooze in particular and the role of marine primary production in general. However, the amount of data used for these calculations is still small and may exhibit large uncertainties.

Streets et al. (24) estimated that about $1130 \mathrm{Gg}$ of $\mathrm{Hg}$ were released from anthropogenic sources to the environment between 1850 and 2010 and $336 \mathrm{Gg}$ of which were emitted directly to the atmosphere. Based on the minimum and maximum $\mathrm{DOHg}_{\mathrm{AR}}$ obtained from Calc.1 and $2\left(397-1322 \mathrm{Mg} \mathrm{yr}^{-1}\right)$, the total amount of $\mathrm{Hg}$ accumulated in diatom ooze in the past 150 years amounts to 22 to $84 \mathrm{Gg}$. This is about 6.5 to $25 \%$ of all $\mathrm{Hg}$ emitted to the atmosphere and 2.0 to $7.4 \%$ of all $\mathrm{Hg}$ released to through anthropogenic emissions in the past 150 years. The remote location and large distance of most diatom ooze sediments from coastlines indicate atmospheric fluxes as the predominant $\mathrm{Hg}$ source. Under this assumption, roughly $20 \%$ of the anthropogenic $\mathrm{Hg}$ emitted to the atmosphere since 1850 may have been buried in diatom ooze alone. This amount may have been even higher taking into account that $\mathrm{DOHg}_{\mathrm{AR}}$ in areas such as Adélie Basin largely exceeds the rates used in our calculation. The unequal distribution of atmospheric $\mathrm{Hg}$ concentrations during the industrial period as well as that of diatom ooze sediments between the hemispheres suggest that $\mathrm{Hg}$ sequestration by diatom ooze might be more important in the Southern than in the Northern Hemisphere, which might reduce the amount of anthropogenic $\mathrm{Hg}$ accumulated in diatom ooze. It is further unknown to what extent the 1 to $5.5 \mathrm{Gg} \mathrm{yr}^{-1}$ of global river discharge of $\mathrm{Hg}$, mainly released to the Northern Ocean (25), contribute to $\mathrm{Hg}$ burial in diatom ooze. However, recent studies indicate that most of this $\mathrm{Hg}$ is buried in estuaries and on the continental shelf (17).

The high $\mathrm{Hg}$ accumulation rates in diatom ooze, which largely surpass the reported $\mathrm{Hg}$ deposition rates to the oceans (1), might be partly explained by increased $\mathrm{Hg}$ fluxes from the atmosphere into the seawater. Similar to $\mathrm{CO}_{2}$, such increased atmospheric $\mathrm{Hg}$ fluxes could be caused by a permanent shift of the dissolution equilibrium (based on Henry's Law constant) toward the dissolved phase if the dissolved phase is permanently removed through $\mathrm{Hg}$ scavenging by the large amount of algae during blooms. We assume that scavenging of water phase $\mathrm{Hg}$ by sinking diatom-organic matter rather than active uptake (see (26) for Hg uptake by algae) is the dominant process of $\mathrm{Hg}$ binding in diatom ooze. Furthermore, dissolved $\mathrm{Hg}$ in the water column will provide a large $\mathrm{Hg}$ pool for scavenging by sinking particles, which could explain the high observed $\mathrm{Hg}$ sedimentation rates (see SI for further discussion). Previous mass-balance models estimated that $96 \%\left(\sim 1300 \mathrm{Mg} \mathrm{yr}^{-1}\right)$ of the atmospheric $\mathrm{Hg}$ flux to the ocean $\left(\sim 1350 \mathrm{Mg} \mathrm{yr}^{-1}\right)$ is re-emitted (1). Even the conservative $\mathrm{Hg}$ accumulation rates in diatom ooze suggest that these high re-emission fluxes are likely overestimated if used on a global scale. A recent model approach on $\mathrm{Hg}$ mass-balance changes during eutrophication in the Baltic Sea estimated a $30-40 \%$ decrease in $\mathrm{Hg}$ evasion during diatom blooms (27) attributed to $\mathrm{Hg}$ sedimentation by algae organic matter. This is in line with findings of $\mathrm{Hg}$ concentrations in settling organic particulate matter in the Atlantic Ocean which suggest that Hg partitioning to particles is up to 1000 times greater than 
suggested by models resulting in decreasing $\mathrm{Hg}$ availability for evasion (28), emphasizing the important role of the marine biological pump for the global $\mathrm{Hg}$ cycle.

The undisturbed $170 \mathrm{~m}$ long annually laminated sediments of Adélie Basin offer an ultra-high resolution $(\sim 2 \mathrm{~cm}$ $\mathrm{yr}^{-1}$ ) record of $\mathrm{Hg}$ accumulation in the oceans spanning large parts of the Holocene (Fig. 3) (13). Hg concentrations in $\mathrm{AB}$ sediments show a median of $32.1 \mathrm{ng} \mathrm{g}^{-1}$ between $\sim 8600$ years and $\sim 1850$ and $\mathrm{Hg}$ accumulation rates largely follow the $\mathrm{Hg}$ concentration record with a median value of $556 \mu \mathrm{g} \mathrm{m}^{-2} \mathrm{yr}^{-1}$. Since $1850, \mathrm{Hg}$ concentrations and accumulation rates increase by a factor of $\sim 2.2$ to median values of $70.9 \mathrm{ng} \mathrm{g}^{-1}$ and $1296 \mu \mathrm{g} \mathrm{m}^{-2} \mathrm{yr}^{-1}$, with local peaks around 1890, 1950, and 1990 , and highest values of $84.5 \mathrm{ng} \mathrm{g}^{-1}$ and $1830 \mu \mathrm{g} \mathrm{m}^{-2} \mathrm{yr}^{-1}$ in 1990. The increase in $\mathrm{Hg}$ accumulation is coincident with the onset of the industrial period and intense coal burning which has been the most important anthropogenic source of $\mathrm{Hg}$ emissions to the atmosphere and global $\mathrm{Hg}$ dispersion. The local peaks in $\mathrm{Hg}$ accumulation during 1900-1920 and 1950-1970 (Fig. 3) correspond to emission peaks calculated based on global $\mathrm{Hg}$ production and consumption rates (24, 29). An indication of a global influence of $\mathrm{Hg}$ emissions from gold and silver mining in the Americas during 1850 and 1910, as estimated in recent models (29), which nearly reach or even surpass levels of those found at times of maximum $\mathrm{Hg}$ emissions during the 20th century, was not found in our cores. Moreover, no anthropogenic influence prior to $\sim 1850$ that could be linked to $\mathrm{Hg}$ emissions from colonial gold mining in South America as suggested by model estimates could be detected (16). The amount of $\mathrm{Hg}$ emitted to the atmosphere by colonial gold mining was probably too low to be detectable in remote Antarctica. Similar, the increase in global atmospheric $\mathrm{Hg}$ loads, as revealed by our Antarctic marine sediment cores, attributed to all time anthropogenic activities is only about a factor of 2.2 , which is slightly lower than in most $\mathrm{Hg}$ records from terrestrial archives $(14,30-32)$, but distinctly lower than current model predictions. This might be due to the fact that most anthropogenic $\mathrm{Hg}$ has been emitted in the Northern Hemisphere so that a larger Hg portion is sequestered there. However, the Southern Ocean is one of the most productive areas on earth and due to the link between primary production and $\mathrm{Hg}$ sequestration likely a large sink for global atmospheric $\mathrm{Hg}$.

\section{REFERENCES AND NOTES}

1. R. P. Mason, G.-R. Sheu, Role of the ocean in the global mercury cycle. Global Biogeochem. Cycles 16, 1093 (2002). doi:10.1029/2001GB001440

2. H. M. Amos, D. J. Jacob, D. G. Streets, E. M. Sunderland, Legacy impacts of all-time anthropogenic emissions on the global mercury cycle. Global Biogeochem. Cycles 27, 410-421 (2013). doi:10.1002/gbc.20040

3. E. M. Sunderland, R. P. Mason, Human impacts on open ocean mercury concentrations. Global Biogeochem. Cycles 21, GB4022 (2007). doi:10.1029/2006GB002876
4. R. P. Mason, W. Fitzgerald, "Sources, sinks and biogeochemical cycling of mercury in the ocean" in Global and Regional Mercury Cycles: Sources, Fluxes and Mass Balances, W. Baeyens, R. Ebinghaus, O. Vasiliev, Eds. (1996), pp. 249-272.

5. S. Strode, L. Jaeglé, S. Emerson, Vertical transport of anthropogenic mercury in the ocean. Global Biogeochem. Cycles 24, GB4014 (2010) doi:10.1029/2009GB003728

6. Y. Zhang, L. Jaegle, L. Thompson, D. G. Streets, Six centuries of changing oceanic mercury. Global Biogeochem. Cycles 28, 1251-1261 (2014). doi:10.1002/2014GB004939

7. C. H. Lamborg, C. R. Hammerschmidt, K. L. Bowman, G. J. Swarr, K. M. Munson, D. C. Ohnemus, P. J. Lam, L.-E. Heimbürger, M. J. A. Rijkenberg, M. A. Saito, A global ocean inventory of anthropogenic mercury based on water column measurements. Nature 512, 65-68 (2014). doi:10.1038/nature13563 Medline

8. W. H. Berger, "Biogenous deep-sea sediments: Production, preservation and interpretation," in Chemical Oceanography (Academic Press, 1976); vol. 5, pp. 265-372.

9. B. Diekmann, Sedimentary patterns in the late Quaternary Southern Ocean. Deep Sea Res. Part II Top. Stud. Oceanogr. 54, 2350-2366 (2007) doi:10.1016/j.dsr2.2007.07.025

10. A. Dutkiewicz, R. D. Müller, S. O. O'Callaghan, H. Jónasson, Census of seafloor sediments in the world's ocean. Geology 43, 795-798 (2015). doi:10.1130/G36883.1

11. Shipboard Scientific Party, "Palmer Deep (Sites 1098 and 1099)" (1999); wwwodp.tamu.edu/publications/178_IR/VOLUME/CHAPTERS/CHAP_07.PDF.

12. Shipboard Scientific Party, "Site 740" (1989); wwwodp.tamu.edu/publications/119_R/VOLUME/CHAPTERS/ir119_09.pdf.

13. C. Escutia, H. Brinkhuis, A. Klaus, Expedition 318 Scientists, "Site U1357" (2011); http://publications.iodp.org/proceedings/318/EXP_REPT/CHAPTERS/318_10 5.PDE.

14. H. Biester, R. Bindler, A. Martinez-Cortizas, D. R. Engstrom, Modeling the past atmospheric deposition of mercury using natural archives. Environ. Sci. Technol. 41, 4851-4860 (2007). doi:10.1021/es0704232 Medline

15. J. Gleason, J. D. Blum, T. C. Moore, L. Polyak, M. Jakobsson, P. A. Meyers, A. Biswas, Sources and cycling of mercury in the paleo Arctic Ocean from $\mathrm{Hg}$ stable isotope variations in Eocene and Quaternary sediments. Geochim. Cosmochim. Acta 197, 245-262 (2017). doi:10.1016/j.gca.2016.10.033

16. H. M. Amos, J. E. Sonke, D. Obrist, N. Robins, N. Hagan, H. M. Horowitz, R. P. Mason, M. Witt, I. M. Hedgecock, E. S. Corbitt, E. M. Sunderland, Observational and modeling constraints on global anthropogenic enrichment of mercury. Environ. Sci. Technol. 49, 4036-4047 (2015). doi:10.1021/es5058665 Medline

17. H. M. Amos, D. J. Jacob, D. Kocman, H. M. Horowitz, Y. Zhang, S. Dutkiewicz, M. Horvat, E. S. Corbitt, D. P. Krabbenhoft, E. M. Sunderland, Global biogeochemical implications of mercury discharges from rivers and sediment burial. Environ. Sci. Technol. 48, 9514-9522 (2014). doi:10.1021/es502134t Medline

18. H. U. Sverdrup, M. W. Johnson, R. H. Fleming, The Oceans: Their Physics, Chemistry, and General Biology (Prentice-Hall, New York, 1942).

19. D. K. Fütterer, "The solid phase of marine sediments" in Marine Geochemistry, H. D. Schulz, M. Zabel, Eds. (Springer Science \& Business Media, ed. 2, 2006).

20. D. J. DeMaster, O. Ragueneau, C. A. Nittrouer, Preservation efficiencies and accumulation rates for biogenic silica and organic $\mathrm{C}, \mathrm{N}$, and $\mathrm{P}$ in high-latitude sediments: The Ross Sea. J. Geophys. Res. Oceans 101, 18501-18518 (1996). doi:10.1029/96JC01634

21. W. H. Berger, The Geology of Continental Margins (Springer, Berlin Heidelberg, 1974), pp. 213-241.

22. M. G. Gross, Oceanography: A View of the Earth (Prentice-Hall, Englewood Cliffs, NJ, 1987), pp. 406

23. P. Tréguer, D. M. Nelson, A. J. Van Bennekom, D. J. Demaster, A. Leynaert, B. Quéguiner, The silica balance in the world ocean: A reestimate. Science 268, 375379 (1995). doi:10.1126/science.268.5209.375 Medline

24. D. G. Streets, H. M. Horowitz, D. J. Jacob, Z. Lu, L. Levin, A. F. H. Ter Schure, E. M. Sunderland, Total mercury released to the environment by human activities. Environ. Sci. Technol. 51, 5969-5977 (2017). doi:10.1021/acs.est.7b00451 Medline

25. J. E. Sonke, L.-E. Heimbürger, Environmental science: Mercury in flux. Nat. Geosci. 5, 447-448 (2012). doi:10.1038/ngeo 1508 
26. S. Le Faucheur, P. G. Campbell, C. Fortin, V. I. Slaveykova, Interactions between mercury and phytoplankton: Speciation, bioavailability, and internal handling. Environ. Toxicol. Chem. 33, 1211-1224 (2014). doi:10.1002/etc.2424 Medline

27. A. L. Soerensen, A. T. Schartup, E. Gustafsson, B. G. Gustafsson, E. Undeman, E. Björn, Eutrophication increases phytoplankton methylmercury concentrations in a coastal sea - A Baltic Sea case study. Environ. Sci. Technol. 50, 11787-11796 (2016). doi:10.1021/acs.est.6b02717 Medline

28. C. H. Lamborg, C. R. Hammerschmidt, K. L. Bowman, An examination of the role of particles in oceanic mercury cycling. Philos. Trans. R. Soc. A 374, 20150297 (2016). Medline

29. H. M. Horowitz, D. J. Jacob, H. M. Amos, D. G. Streets, E. M. Sunderland, Historical Mercury releases from commercial products: Global environmental implications. Environ. Sci. Technol. 48, 10242-10250 (2014). doi:10.1021/es501337j Medline

30. D. R. Engstrom, W. F. Fitzgerald, C. A. Cooke, C. H. Lamborg, P. E. Drevnick, E. B. Swain, S. J. Balogh, P. H. Balcom, Atmospheric Hg emissions from preindustrial gold and silver extraction in the Americas: A reevaluation from lake-sediment archives. Environ. Sci. Technol. 48, 6533-6543 (2014). doi:10.1021/es405558e Medline

31. S. A. Beal, B. P. Jackson, M. A. Kelly, J. S. Stroup, J. D. Landis, Effects of historical and modern mining on mercury deposition in southeastern Peru. Environ. Sci. Technol. 47, 12715-12720 (2013). doi:10.1021/es402317x Medline

32. S. Eyrikh, A. Eichler, L. Tobler, N. Malygina, T. Papina, M. Schwikowski, A 320 year ice-core record of atmospheric Hg pollution in the Altai, central Asia. Environ. Sci. Technol. 51, 11597-11606 (2017). doi:10.1021/acs.est.7b03140 Medline

33. International Ocean Discovery Program, http://web.iodp.tamu.edu/LORE/ (2017).

34. J. Kim, B. K. Khim, Holocene paleoclimate change in the Adélie Basin, East Antarctica (IODP EXP 318 Site U1357) presented at the GSA Annual Meeting, Vancouver, British Columbia, 19-22 October 2014.

35. M. Yamane, Y. Yokoyama, Y. Miyairi, H. Suga, H. Matsuzaki, R. B. Dunbar, N. Ohkouchi, Compound-specific ${ }^{14} \mathrm{C}$ dating of IODP Expedition 318 core U1357A obtained off the Wilkes Land Coast, Antarctica. Radiocarbon 56, 1009-1017 (2014). doi:10.2458/56.17773

36. E. Domack, A. Leventer, R. Dunbar, F. Taylor, S. Brachfeld, C. Sjunneskog, Chronology of the Palmer Deep site, Antarctic Peninsula: A Holocene palaeoenvironmental reference for the circum-Antarctic. Holocene 11, 1-9 (2001). doi:10.1191/095968301673881493

37. E. Domack, A. J. Jull, D. Donahue, "Holocene chronology for the unconsolidated sediments at Hole 740A: Prydz Bay, East Antarctica" in Proceedings of the Ocean Drilling Program, Vol. 119, Scientific Results, Kerguelen Plateau-Prydz Bay, J. Barron, B. Larsen, Eds. (ODP, Texas A\&M University, College Station, 1991), pp. 747-750.

38. X. Crosta, M. Debret, D. Denis, M. Courty, O. Ther, Holocene long- and short-term climate changes off Adelie Land, East Antarctica. Geochem. Geophys. Geosyst. 8, Q11009 (2007). doi:10.1029/2007GC001718

39. P. Campagne, X. Crosta, S. Schmidt, M. Noëlle Houssais, O. Ther, G. Massé, Sedimentary response to sea ice and atmospheric variability over the instrumental period off Adélie Land, East Antarctica. Biogeosciences 13, 42054218 (2016). doi:10.5194/bg-13-4205-2016

40. H. Brinkhuis et al., "Wilkes land glacial history Cenozoic East Antarctic ice sheet evolution from Wilkes Land margin sediments" (2010).

41. A. K. Cheburkin, W. Shotyk, AnEnergy-dispersive Miniprobe Multielement Analyzer (EMMA) for direct analysis of $\mathrm{Pb}$ and other trace elements in peats. Fresenius $\mathrm{J}$. Anal. Chem. 354, 688-691 (1996). Medline

42. U.S. Environmental Protection Agency, (EPA), "Mercury in solids and solutions by thermal decomposition, amalgamation, and atomic absorption spectrophotometry" (1998).

43. M. J. Baxter, I. C. Freestone, Log-ratio compositional data analysis in archaeometry. Archaeometry 48, 511-531 (2006). doi:10.1111/j.14754754.2006.00270.x

44. R Core Team, R: A language and environment for statistical computing (Vienna, Austria, R Foundation for Statistical Computing, 2014)

45. T. M. Conway, S. G. John, The biogeochemical cycling of zinc and zinc isotopes in the North Atlantic Ocean. Global Biogeochem. Cycles 28, 1111-1128 (2014). doi:10.1002/2014GB004862
46. R. Chester, Marine Geochemistry (Blackwell Science, London, ed. 2, 2000).

47. N. Cameron, The use of diatom analysis in forensic geoscience. Geol. Soc. Lond. Spec. Publ. 232, 277-280 (2004). doi:10.1144/GSL.SP.2004.232.01.25

48. X. Crosta, O. Romero, L. K. Armand, J.-J. Pichon, The biogeography of major diatom taxa in Southern Ocean sediments: 2. Open ocean related species. Palaeogeogr. Palaeoclimatol. Palaeoecol. 223, 66-92 (2005). doi:10.1016/i.palaeo.2005.03.028

49. D. M. Nelson, P. Tréguer, M. A. Brzezinski, A. Leynaert, B. Quéguiner, Production and dissolution of biogenic silica in the ocean: Revised global estimates, comparison with regional data and relationship to biogenic sedimentation. Global Biogeochem. Cycles 9, 359-372 (1995). doi:10.1029/95GB01070

50. O. Ragueneau, P. Tréguer, A. Leynaert, R. F. Anderson, M. A. Brzezinski, D. J. DeMaster, R. C. Dugdale, J. Dymond, G. Fischer, R. François, C. Heinze, E. MaierReimer, V. Martin-Jézéquel, D. M. Nelson, B. Quéguiner, A review of the Si cycle in the modern ocean: Recent progress and missing gaps in the application of biogenic opal as a paleoproductivity proxy. Global Planet. Change 26, 317-365 (2000). doi:10.1016/S0921-8181(00)00052-7

51. P. J. Tréguer, C. L. De La Rocha, The world ocean silica cycle. Annu. Rev. Mar. Sci. 5, 477-501 (2013). doi:10.1146/annurev-marine-121211-172346 Medline

52. V. Roubeix, S. Becquevort, C. Lancelot, Influence of bacteria and salinity on diatom biogenic silica dissolution in estuarine systems. Biogeochemistry 88, 47-62 (2008). doi:10.1007/s10533-008-9193-8

53. J. Jansen, N. A. Hill, P. K. Dunstan, J. McKinlay, M. D. Sumner, A. L. Post, M. P. Eléaume, L. K. Armand, J. P. Warnock, B. K. Galton-Fenzi, C. R. Johnson, Abundance and richness of key Antarctic seafloor fauna correlates with modelled food availability. Nat. Ecol. Evol. 2, 71-80 (2018). doi:10.1038/s41559-017-03923 Medline

54. K. M. Munson, C. H. Lamborg, G. J. Swarr, M. A. Saito, Mercury species concentrations and fluxes in the Central Tropical Pacific Ocean. Global Biogeochem. Cycles 29, 656-676 (2015). doi:10.1002/2015GB005120

\section{ACKNOWLEDGMENTS}

We thank P. Rumford (Golf Coast Repository), W. Hale and H. Kuhlmann (Bremen Core Repository) for providing samples, A. Calean and P. Schmidt for technical assistance. Funding: This work was funded by Technische Universität Braunschweig. Author contributions: SZ carried out the laboratory analyses and MPR performed the statistical analyses. HB conceived of the research. All authors contributed equally to data interpretation and manuscript writing. Competing interests: The authors declare no competing interests. Data and materials availability: All data are available in the supplementary materials.

\section{SUPPLEMENTARY MATERIALS}

www.sciencemag.org/cgi/content/full/science.aat2735/DC1

Materials and Methods

Supplementary Text

Figs. S1 to S4

Tables S1 to S14

References (33-54)

9 February 2018; accepted 7 July 2018

Published online 26 July 2018

10.1126/science.aat2735 


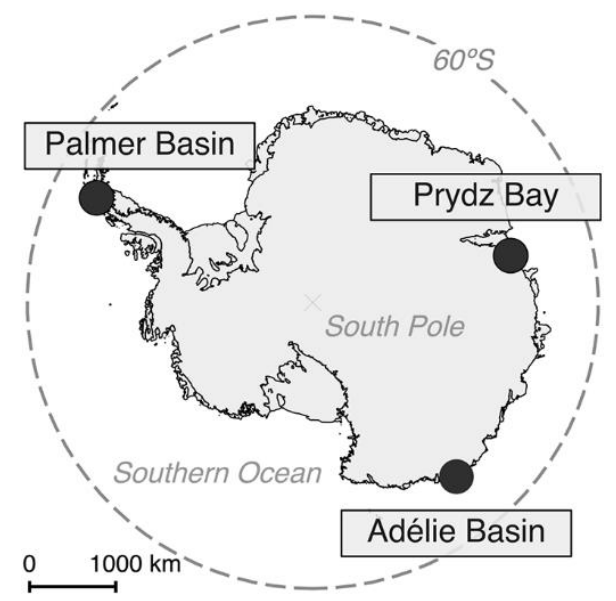

Adélie Basin (AB)

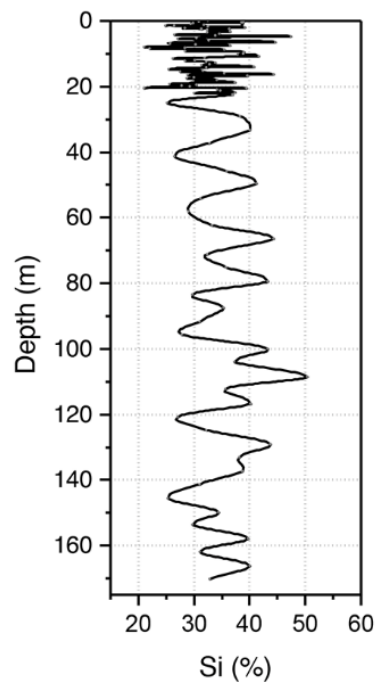

Fig. 1. Map of core sites. Locations of the investigated cores in Antarctica: Prydz Bay core, ODP Expedition 119 site 740; Palmer Basin core, ODP Expedition 178 Site 1098; and Adélie Basin core, IODP Expedition 318 Site U1357.

ANTARCTICA IMAGE SOURCE: (C) BRITISH ANTARCTIC SURVEY
Palmer Basin (PB)

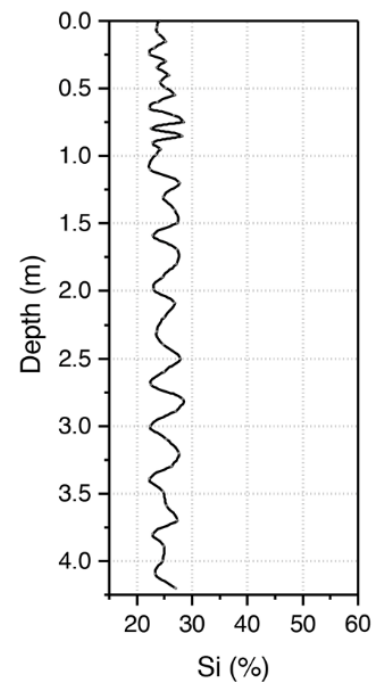

Prydz Bay (PrB)

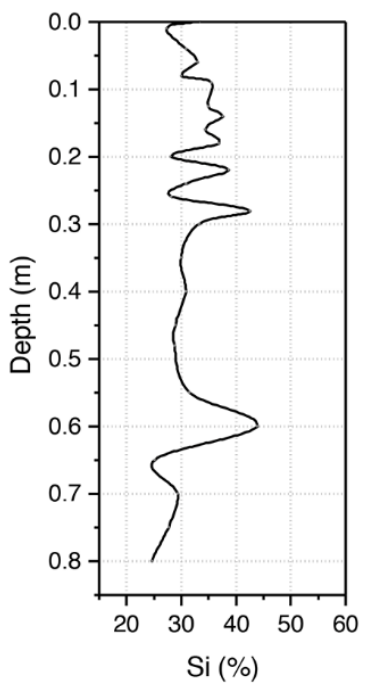

Fig. 2. Silicon concentrations in diatom ooze sediments. Downcore records of silicon (Si) concentrations in Adélie Basin (AB), Palmer Basin (PB) and Prydz Bay (PrB) sediments (Note the difference in the length of the cores). 


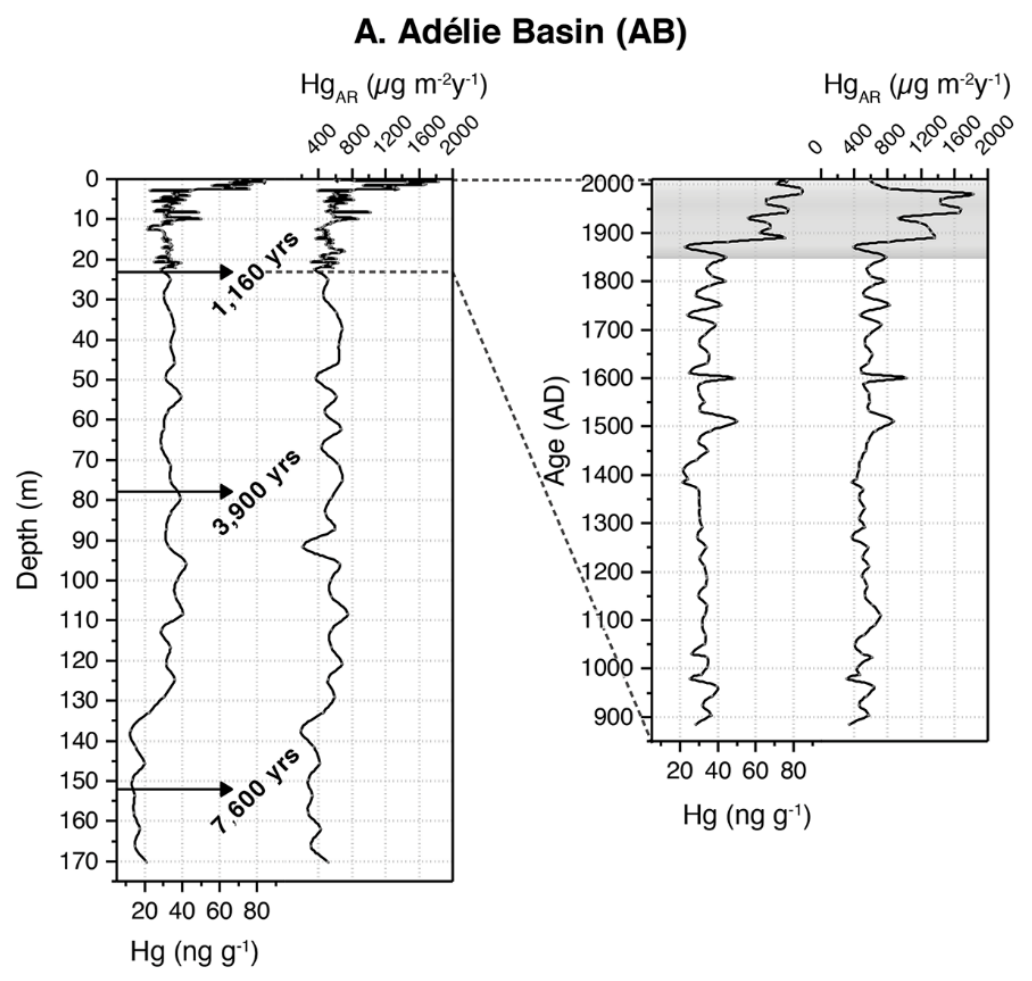

\section{B. Palmer Basin (PB) C. Prydz Bay (PrB)}

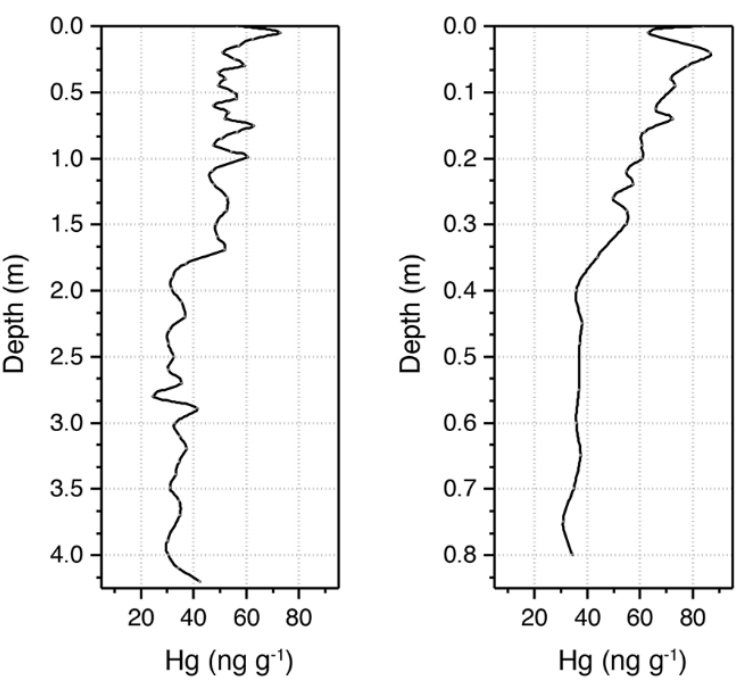

Fig. 3. Mercury concentration and accumulation rate in diatom ooze sediments. (A to $C$ ) Down core records of mercury (Hg) concentrations in Adélie Basin (AB), Palmer Basin (PB) and Prydz Bay (PrB), and mercury accumulation rates $\left(\mathrm{Hg}_{\mathrm{AR}}\right)$ in $\mathrm{AB}$ sediments. The shaded section in panel $\mathrm{A}$, represents the industrial period. Average sedimentation rate of $2 \mathrm{~cm} \mathrm{yr}^{-1}$ was used for chronology construction of $A B$ (13). Median background $\mathrm{Hg}$ concentration equal 32.1, 34.5 and $36.0 \mathrm{ng} \mathrm{g}^{-1}$ with median absolute deviation of 2.74, 2.21 and 1.20 for AB, PB and PrB, respectively (note the difference in the length of the cores). 
Table 1. Global annual mercury accumulation and total accumulated mercury in diatom ooze sediments. Global

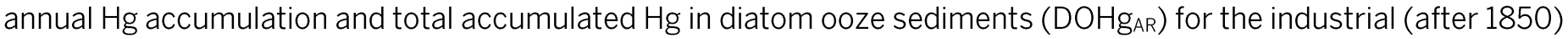
and the pre-industrial (before 1850) period calculated from Calc.1: a diatom ooze area of $23.3-31.1 \mathrm{Mio} \mathrm{km}^{2}(10,18)$ and a sedimentation rate of $0.75 \mathrm{~mm} \mathrm{yr}^{-1}$ as suggested for Antarctic diatom ooze (19) and average $\mathrm{Hg}$ concentrations for the pre-industrial and the industrial period derived from AB, PrB and PB cores, and Calc.2: based on the annual accumulation of biogenic silica (BSi) in the world's oceans (23) assuming BSi preservation of 30,60 and $80 \%$ and the average $\mathrm{Si} / \mathrm{Hg}$ ratios for the pre-industrial and the industrial period derived from $\mathrm{AB}, \mathrm{PrB}$ and $\mathrm{PB}$ cores.

\begin{tabular}{lllll} 
Calculation & $\begin{array}{l}\mathbf{D O H g}_{\mathbf{A R}} \\
\text { pre-industrial } \\
\left(\mathbf{M g ~ y r}^{-1}\right)\end{array}$ & $\begin{array}{l}\mathbf{D O H g}_{\mathbf{A R}} \\
\text { industrial period } \\
\left(\mathbf{M g ~ y r}^{-\mathbf{1}}\right)\end{array}$ & Enrichment factor & $\begin{array}{l}\text { DO-stored pollution Hg } \\
\text { since } \mathbf{~ 1 8 5 0} \\
(\mathbf{G g})\end{array}$ \\
\hline Calc. 1 & $574 / 765$ & $992 / 1322$ & 1.7 & $63 / 84$ \\
Calc. 2 & $230 / 460 / 613$ & $397 / 758 / 1010$ & 1.6 & $22 / 45 / 60$ \\
$\begin{array}{c}\text { Average Calc. 1 and 2 } \\
\text { (range based on 2) }\end{array}$ & $497 / 613 / 689$ & $850 / 1040 / 1166$ & 1.7 & $53 / 64 / 72$ \\
\hline
\end{tabular}

